\title{
RECIPROCAL TEACHING BERBASIS TEKNOLOGI DENGAN PENDEKATAN ASSURE DI PERGURUAN TINGGI
}

\author{
Hasan Baharun* \& Lailatur Rizqiyah** \\ Universitas Nurul Jadid \\ *ha54nbaharun@gmail.com \\ **lailaturrizqiyah96@gmail.com
}

\begin{abstract}
This paper presents a model of learning about the use of reciprocal teaching with technology-based approach to ASSURE that will be applied in college. Reciprocal Teaching is becoming one of the learning models that train students to learn independently and active. With the existence of reciprocal learning teaching model of application students are expected to carry out and follow the learning effectively and efficiently. The learning process is basically a direct interaction between the students and educators held aims to to a destination that has meant. In addition the interaction process will bear an effective communication as well as the need for a development that is both instructional media with a melaluli approach to ASSURE. Approach to ASSURE the approach can be a designing a learning through technology-based media. This is necessary in order to set up and customize the process of learning in college by making the liveliness, creativity and independence as well as encourage students to berantusias in studying diligently and follow the lectures. So it is with the application of the reciprocal teaching and pendekatanASSURE in college could create conditions that are more meaningful and enable them to build better personality and character and self-reliance in learning.
\end{abstract}

Keywords: Reciprocal Teaching, approach to ASSURE and College

\begin{abstract}
Abstrak: Tulisan ini menyajikan tentang penggunaan model pembelajaran reciprocal teaching berbasis teknologi dengan pendekatan ASSURE yang akan diterapkan di perguruan tinggi. Reciprocal Teaching menjadi salah satu model pembelajaran yang melatih mahasiswa untuk belajar mandiri dan aktif. Dengan adanya penerapan model pembelajaran reciprocal teaching mahasiswa diharapkan dapat melaksanakan dan mengikuti pembelajaran dengan efektif dan efisien. Proses pembelajaran pada dasarnya merupakan sebuah interaksi langsung antara para pelajar dan pendidik yang penyelenggaraannya bertujuan untuk untuk sebuah tujuan yang telah direncakan. Selain itu proses interaksi tersebut akan melahirkan sebuah komunikasi yang efektif serta diperlukannya sebuah pengembangan media yang bersifat instruksional dengan melaluli pendekatan ASSURE. Pendekatan ASSURE menjadi sebuah pendekatan yang dapat mendesain sebuah pembelajaran melalui media yang berbasis teknologi. Hal ini diperlukan sebagai upaya untuk mengatur dan mengkondisikan proses pembelajaran di perguruan tinggi dengan menjadikan keaktifan, kekreatifan dan kemandirian serta mendorong mahasiswa untuk berantusias dalam belajar tekun dan
\end{abstract}


mengikuti perkuliahan. Sehingga dengan adanya penerapan reciprocal teaching dan pendekatan ASSURE di perguruan tinggi bisa menciptakan kondisi yang lebih bermakna dan mengaktifkan mereka untuk membangun lebih baik kepribadian dan karakter serta kemandirian dalam belajar.

Kata kunci: Reciprocal Teaching, ASSURE, Perguruan Tinggi

\section{PENDAHULUAN}

Pada dasarnya pendidikan merupakan suatu kesatuan dalam pembelajaran dan termasuk salah satu sektor pembangunan yang tidak bisa dianggap remeh lagi karena dalam menghadapi persaingan dengan negara lain pada era 15 tahun kedepan yang dijadikan penentu atau senjata untuk melawannya adalah dengan wujud dan kemajuan suatu pendidikan ${ }^{1}$. Maka, pedidikan yang baik adalah pendidikan yang mampu melahirkan generasi-generasi pelajar yang bermutu dan tertanam semangat jiwa dalam belajar.

Menurut Lodge ${ }^{2}$, pendidikan merupakan life is education and education is life, atau bisa diartikan sebagai proses kehidupan dan juga sebagai kehidupan manusia yang cenderung berjalan sesuai dengan apa yang ada dihadapan manusia serta tidak akan bisa terpisahkan satu dengan yang lainnya.

Di samping pendidikan sangat berarti dalam setiap kehidupan, hadirnya pendidikan tidak akan terasa sempurna tanpa adanya suatu proses yang mendukung dalam pembangunan pendidikan, diantara proses tersebut adalah adanya model pembelajaran ${ }^{3}$. Model pembelajaran merupakan sebuah interpretasi dari hasil observasi yang perolehannya di dapat melalui beberapa sistem ${ }^{4}$, atau secara sederhana dapat diartikan sebagai sebuah rancangan yang dengan sengaja disusun secara sistematis sebagai wujud pengorganisasian bahan pembelajaran dengan tujuan dapat membantu proses pembelajaran yang hendak dibawa dan disajikan oleh guru.

Dengan demikian, adanya penyelenggaraan pendidikan yang ada dalam sebuah lembaga pendidikan akan berjalan sesuai dengan yang diinginkan. Selain itu,

1 Surya Dharma \& Husaini Usman, 'Konsepsi Dan Aksi Sinergi Perguruan Tinggi, Pemerintah Daerah, Dan Dunia Usaha/Industri', Jurnal Ilmu Pendidikan, 14.1 (2007), 1-9.

2 Kasuwi, 'Upaya Peningkatan Kualitas Pendidikan Agama Di Perguruan Tinggi Umum', Jurnal Ilmu Pendidikan, 13.2 (2006), 69-74.

${ }^{3}$ Hasan Baharun, 'Pengembangan Media Pembelajaran PAI Berbasis Lingkungan Melalui Model ASSURE', Cendekia: Journal of Education and Society, 14.2 (2016), 231-46.

${ }^{4}$ I Gd Meter dan I Ketut Ardana Ni Wyn Pradnya Mitha, 'Model Pembelajaran ASSURE Bernuansa Lingkungan Berbantuan Media Audiovisual Berpengaruh Terhadap Hasil Belajar IPS Siswa Kelas V SD Gugus Letkol Wisnu', Jurnal Mimbar PGSD, 2.1 (2014), 1-11. 
meski pendidikan yang berada di lembaga formal menyediakan dengan berbagai macam model pembelajaran, sistem pendidikan yang berada di perguruan tinggi tidak kalah saing dalam pelaksanaan pembelajarannya ${ }^{5}$, karena perguruan tinggi merupakan suatu lembaga yang mampu untuk mempertanggung jawabkan keadaan sumber daya manusia (SDM) dalam menguasai dan memahami IPTEK ${ }^{6}$.

Bertolak belakang dari hal tersebut, banyak dari kalangan peneliti, pengamat dan juga praktisi berpendapat bahwa penyelenggaraan proses pembelajaran yang ada di perguruan tinggi masih dibawah kualitas yang diharapkan, baik dalam visi, misi maupun tujuan pendidikan tersebut ${ }^{7}$.

Menurut Hamzah dan $\mathbf{R a h m a n}^{8}$, dalam pelaksanaan proses pembelajaran mahasiswa cenderung malas dan tidak bersemangat dalam mengikuti perkuliahan. Hal tersebut terjadi karena pada saat kegiatan pembelajaran mahasiswa hanya membawa alat perkuliahan seadanya, misalkan satu atau dua lembar kertas. Selain itu, mahasiswa juga tampak tidak terhipnotis atau tidak tertarik dalam mencari referensi lain sebagai wujud penambahan materi perkuliaannya.

Sedangkan Budihardjo ${ }^{9}$ berpendapat bahwa potret kegiatan pembelajaran di perguruan tinggi meliputi: 1) adanya proses pembelajaran yang dijejali dengan teori, sehingga proses tersebut menjadikan hilangnya kecakapan praktisi sebagai bentuk tuntutan dalam kebutuhan baik dalam dunia kerja, bisnis meupun industri. 2) Lecturer Oriented atau Faculty Centered, pola pembelajaran yang seperti ini menjadikan mahasiswa pasif. 3) adanya teori yang digunakan dalam mata kuliah umumnya berasal dari barat sehingga menjadikan hilangnya relevansi dengan kondisi di perguruan tinggi khususnya di Indonesia.

Berdasarkan hal tersebut, untuk mewujudkan cita-cita dan harapan yang ada dalam lembaga pendidikan, maka digunakanlah suatu model pembelajaran dengan pendekatannya sebagai wujud untuk membantu terlaksananya proses pembelajaran yang efektif dan efisien.

${ }^{5}$ Iwan Jazadi, 'Evaluasi Dan Pengembangan Proses Belajar-Mengajar Di Perguruan Tinggi', Jurnal Ilmu Pendidikan, 12.1 (2005), 1-17.

${ }^{6}$ Surya Dharma \& Husaini Usman.

${ }^{7}$ Iwan Jazadi.

${ }^{8}$ Iwan Jazadi.

${ }^{9}$ Iwan Jazadi. 


\section{RECIPROCAL TEACHING : MODEL PEMBELAJARAN INOVATIF}

Pada tahun 1982, Reciprocal Teacbing merupakan sebuah model pembelajaran yang dikembangkan pertama kali oleh Palincsar dan dioperasikan atau digunakan bersama dengan Brown pada tahun 1984. ${ }^{10}$ Reciprocal teaching di sini merupakan model pembelajaran yang sangat mudah untuk digunakan dan diterapkan dalam sebuah pembelajaran. Karena Reciprocal Teaching selain sebagai model pembelajaran juga merupakan suatu pengenalan tentang prosedur dalam pembelajaran yang di rancang untuk mendidik mahasiswa mengenai strategi-strategi kognitif yang dapat membantu mahasiswa dalam memahami materi perkuliahan ${ }^{11}$. Adapun strategi yang terdapat dalam model pembelajaran reciprocal teaching ialah dengan menerapkan empat strategi kognitif ${ }^{12}$, diantaranya: 1) menyimpulkan bahan ajar, 2) menyusun pertanyaan dan menyelesaikannya, 3) menjelaskan kembali pengetahuan yang diperoleh dan 4) memprediksikan pertanyaan selanjutnya.

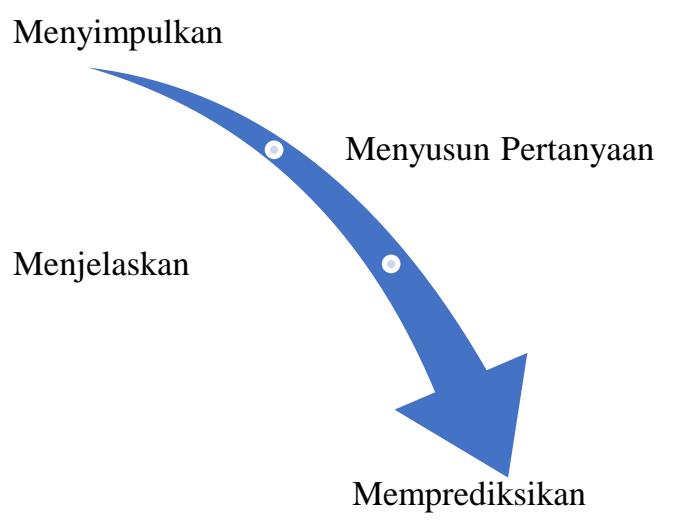

Gambar 1.1 : bagan tentang strategi kognitif dalam model pembelajaran Reciprocal Teaching

10 Yuli Andriana. Hasan Baharun, Vidyatul Muyassaroh, Model Dan Desain Pembelajaran Inovatif, Kreatif Dan Berkarakter (Probolinggo: Pustaka Nurja bekerjasama dengan Duta Media, 2018).

${ }^{11}$ Suwardi dan Jaslin Ikhlas Eli Rohaeti, Peningkatan Prestasi Dan Kemandirian Belajar Mahasiswa Melalui Pendekatan, 2010.

12 Aidil Adhani, 'Pengaruh Strategi Pembelajaran Reciprocal Teaching Dan Kemampuan Akademik Terhadap Aktivitas Lisan Dan Hasil Belajar Kognitif Biologi', Jurnal Pendidikan Sains, 2.3 (2014), 148-58. 
Dari keempat strategi tersebut, maka mahasiswa akan melaksanakan aktivitas perkuliahan sesuai dengan apa yang telah menjadi aturan dan hal tersebut akan menjadikan mahasiswa memiliki kesempatan untuk meningkatkan aktivitas kognitif yang dimilikinya ${ }^{13}$.

Berdasarkan apa yang dikemukakan oleh Palincsar ${ }^{14}$ bahwa reciprocal teaching was a series of learning activities included to read learning materials, to draw a conclusion, to pose questions, to explain and to compile a prediction. Sehingga dalam penerapan model pembelajaran dengan reciprocal learning diperlukan adanya kerja sama antara kegiatan satu dengan kegiatan yang lain seperti membaca bahan-bahan pembelajaran dengan tujuan berupaya dalam menarik kesimpulan, mengajukan pertanyaan, dan menjelaskan serta mengkompilasi prediksi belajar.

Menurut Wikandari ${ }^{15}$, Reciprocal Teaching merupakan sebuah pendekatan yang kontruktivis dengan berbagai prinsip-prinsip yang dilakukan dengan proses pembelajaran langsung dan pemantauan dari pengajar untuk mengetahui kinerja belajar siswa. Sehingga dengan menggunakan model pembelajaran reciprocal teaching dapat mendukung terhadap siswa dalam kegiatan bertukar pikiran dalam hal pengalaman, pengetahuan, dan wawasan, dengan tujuan dapat melengkapi satu sama lainnya.

Reciprocal Teaching disebut juga sebagai model pembelajaran terbalik yang terfokus pada memberikan kesempatan terhadap mahasiswa dalam aktif mengikuti pembelajaran $^{16}$. Model pembelajaran ini juga mampu merangsang mahasiswa dalam menyelami pikirannya sendiri serta memotivasi dirinya sendiri dengan cara mengajukan beberapa kalimat yang dijadikan sebuah pertanyaan dan mempersentasikannya.

Sehigga secara sederhana, Reciprocal Teaching merupkan suatu alat yang dapat memonitor atau memantau pemahaman mahasiswa dengan cara menggantikan posisi

13 Adhani.

14 Abdul Qohar dan Utari Sumarmo, 'Improving Mathematical Communication Ability and Self Regulation Learning Of Yunior High Students by Using Reciprocal Teaching', IndoMS. J.M.E, 4.1 (2013), 59-74.

15 D.B.K.T Ngr. dan Semara Putra I Komang Agus Sethiawan, IGA Agung Sri Asri, 'Pengaruh Model Pembelajaran Terbalik ( Reciprocal Teaching) Berbantuan Media Grafis Terhadap Hasil Belajar IPS Siswa Kelas V Semester II SD Gugus I Gusti Ketut Jelantik', Jurnal Mimbar PGSD, 2.1 (2014), 2014.

${ }^{16}$ Hasan Baharun, Vidyatul Muyassaroh. 
sementara ${ }^{17}$, dalam artian posisi dosen diganti oleh mahasiswa dan dosen menjadi motivator sebagai bentuk tujuan untuk mendukung proses terjadinya suatu diskusi mengenai mata kuliah tertentu.

Dalam model pembelajaran Reciprocal Teaching mahasiswa diberi kebebasan untuk mengembangkan proses berpikirnya dalam menemukan sebuah ide atau pengetahuan dan memudahkan untuk belajar dalam memecahkan suatu permasalahan dalam pembelajaran yang disesuaikan dengan prinsip dalam pendekatan metakognitif ${ }^{18}$.

Pembelajaran Reciprocal Teaching juga mendidik mahasiswa untuk berkomunikasi dan berinteraksi sosial dengan sesamanya guna mencapai dalam tujuan pembelajaran yang dikehendakinya ${ }^{19}$ dan menjadikan mahasiswa terus menggali informasi yang masih belum diketahui dalam artian menjadikan mahasiswa untuk aktif beromunikasi dalam mengetahui berbagai macam informasi-informasi ${ }^{20}$.

Dengan demikian, proses pembelajaran terjadi atas dasar adanya kemandirian mahasiswa yang tercipta dalam hubungan berkonstribusi dengan media pembelajaran yang berupa Reciprocal Teaching. Selain menciptakan kemandirian, untuk proses pembelajarannya harus disertai dengan langkah-langkah ${ }^{21}$ sebagai berikut:

1. Setelah siswa duduk dengan anggota kelompoknya maka guru menyiapkan materi ajar yang harus dipelajari peserta didik secara mandiri

2. Peserta didik melaksanakan tugasnya dalam kelompok sebagai berikut;

a. Mempelajari materi yang dibahas hari ini dengan mandiri (membaca) kemudian secara bergantian pada sub materi siswa berperan menjadi guru menjelaskan materi yang dibaca kepada anggota kelompoknya

17 Burhanuddin dan Wahyu Kurniati Asri Sriyani Ketong, 'Keefektifan Model Pembelajaran Reciprocal Teaching Dalam Kemampuan Membaca Memahami Siswa Kelas XI IPA SMA Negeri 11 Makassar', Eralingua: Jurnal Pendidikan Bahasa Asing Dan Sastra, 2.1 (2018), 45-54.

18 Afandi, 'Pembelajaran Biologi Menggunakan Pendekatan Metakognitif Melalui Model Reciprocal Teaching Dan Problem Based Learning Ditinjau Dari Kemandirian Belajar Dan Kemampuan Berpikir Kritis Mahasiswa', Jurnal Pendidikan Matematika Dan IPA, 2.2 (2011), 1-7.

${ }_{19}$ Ria Sardiyanti, 'Penerapan Model Pembelajaran Terbalik ( Recprocal Teaching ) Untuk Meningkatkan Aktivitas Belajar Matematika Siswa', Penelitian Tindakan Kelas Di MTs Daarul Hikmah Pamulang, 2010, pp. 1-243.

${ }^{20}$ Widiya Pakartining Kawedar \& Abdul Qohar, 'Penerapan Model Pembelajaran Reciprocal Teaching Untuk Meningkatkan Hasil Belajar Siswa Pada Pokok Bahasan Segitiga Siswa Kelas VII-C SMP Negeri 2 Kepanjen', Jurnal Matematika, 2.2 (2015), 1-9.

${ }^{21}$ Hasan Baharun, Vidyatul Muyassaroh. 
b. Setelah kegiatan membaca dan siswa berperan sebagai guru pada kelompok kecilnya maka dilanjutkan dengan kegiatan reciprocal teaching di mana siswa berperan menerapkan 4 strategi pemahaman yaitu membuat pertanyaan, menjawab pertanyaan, membuat pertanyaan lanjutan, dan merangkum bahan ajar

c. Diskusi mengerjakan latihan soal pada lembar aktivitas siswa

3. Guru berkeliling mengamati keaktifan dari masing- masing peserta didik saat melakukan kegiatan reciprocal teaching dalam diskusi kelompok

\section{ASSURE SEBAGAI PENDEKATAN PEMBELAJARAN}

Pendidikan dijadikan sebagai suatu hal yang sangat urgen dalam kehidupan manusia sebagai wujud motivasi untuk menjadikannya berpikir secara positif dalam memasuki era modern saat ini. Dalam kalangan saat ini, untuk mencapai hal tersebut dibutuhkanlah suatu usaha yang dapat menjadikannya suatu kenyataan, maka diciptakanlah suatu lembaga pendidikan yang dapat menampung berbagai macam pemikirin yang dituang oleh mahasiswa ${ }^{22}$.

Selain demikian, dengan maraknya teknologi saat ini yang sudah semakin canggih maka pendidikan yang ada mengharuskan untuk menggunakan kemampuan teknologi ${ }^{23}$. Disamping itu, kecanggihan teknologi tersebut dijadikan sebuah alasan untuk meningkat kualitas manajemen dan proses pembelajaran yang ada di perguruan tinggi ${ }^{24}$.

Peningkatan manajemen tersebut dibuktikan dengan adanya penerapan suatu pembelajaran dalam sebuah mata kuliah di perguruan tinggi dengan menggunakan sebuah pendekatan berbasis teknologi yang disebut ASSURE ${ }^{25}$. Pada pendekatan ASSURE, pembelajaran terlaksana dengan adanya rancangan dan pengembangan untuk menciptakan sebuah aktivitas pembelajaran yang efektif dan efisien ${ }^{26}$.

${ }^{22}$ Yudi Yunika Putra and Adi Saputra, 'Pengembangan Blog Support Mata Kuliah', 11.2 (2018), 179-92.

23 Putra and Saputra.

${ }^{24}$ Putra and Saputra.

${ }^{25}$ Widia Maya Sari dan Endang Susiloningsih, 'Penerapan Model ASSURE Dengan Metode Problem Solving Untuk Meningkatkan Keterampilan Berpikir Kritis', Jurnal Inovasi Pendidikan Kimia, 9.1 (2015), 1468-77.

${ }^{26}$ Widia Maya Sari dan Endang Susiloningsih. 
Pendekatan ASSURE pada awalnya dikembangkan oleh Sharon Smaldino, Robert Heinich, Jemes Russel dan Michael Molenda yang dicantumkan dalam sebuah buku yang berjudul "Intructional Technology and Media for Learning" 27 . ASSURE merupakan suatu pendekatan yang terdapat dalam model pembelajaran yang didesain secara sistematis dan menyeluruh yang memanfaatkan pada adanya media dan teknologi dalam menciptakan suatu pemandangan proses pembelajaran yang menarik, efektif dan efisien ${ }^{28}$.

Sejalan dengan pernyataan yang dikemukakan oleh Heinich $^{29}$ bahwa ASSURE merupakan suatu pendekatan pembelajaran yang didalamnya didesain dengan adanya faktor pemanfaatan media dan bahan pembelajaran yang telah disusun dan direncakan, sehingga dapat merangsang mahasiswa untuk belajar secara aktif dan efisien.

Menurut Pribadi ${ }^{30}$ ASSURE merupakan sebuah akronim yang memiliki kepanjangan Analyze lerner characteristics, State performance objectives, Select methods, media, and materials, Utilize materials, Require learner participation, Evaluate and revise. Selain hal tersebut, pemanfaatan dari ASSURE ialah perlu adanya proses yang dilakukan secara bertahap dengan tujuan agar tercipta sebuah pembelajaran yang optimal dan sukses ${ }^{31}$.

Berdasarkan dari penjelasan tentang akronim dalam ASSURE, maka terdapat beberapa penjelasan mengenai komponen-komponen yang terdapat dalam ASSURE $^{32}$ diantaranya:

1. Analyze lemer characteristics, langkah pertama yang dilakukan adalah mengidentifikasi karakteristik yang terdapat dalam jiwa mahasiswa sehingga dapat menyesuaikan dengan hal-hal yang dibutuhkan dalam proses pembelajaran. Tujuannya adalah sebagai upaya untuk mengetahui segala sesuatu yang dibutuhkan oleh mahasiswa

${ }_{27}$ Rosmalia Eva, 'Pengaruh Aplikasi Model ASSURE Terhadap Motivasi Dan Hasil Belajar Peserta Didik Dalam Pembelajaran Georafi', Jurnal Pendidikam Geografi, 15.2 (2015), 8-14.

${ }^{28}$ Hasan Baharun, Vidyatul Muyassaroh.

${ }^{29}$ Tri Saptuti S. dan Kartika Chrysti S. Irma Fatehkatun Kasanah, 'Aplikasi Model ASSURE Berbasis Pendidikan Karakter Untuk Meningkatkan Pembelajaran Tema Sejarah Peradaban Indonesia Siswa Kelas V SDN 1 Klapasawit', Jurnal Ilmu Pendidikan, 2.2 (2015), 1-5.

${ }^{30}$ Widia Maya Sari dan Endang Susiloningsih.

31 Thamrin Kamaruddin dan M. Yusuf Harun Winda Maulina, 'Penerapan Model Pembelajaran ASSURE Untuk Meningkatkan Hasil Belajar Geografi Siswa Kelas XI IPS SMA Negeri 12 Banda Aceh', Jurnal Ilmiah Mahasiswa Pendidikan Geografi, I.1 (2016), 203-11.

32 Siti Zulaikha dan I Md. Suara I Gusti Ayu Martha Sari, 'Pengaruh Model Pembelajaran ASSURE Berbasis Concept Mapping Terhadap Hasil Belajar IPS Siswa Kelas V SD Gugus Letkol Wisnu Denpasar Utara', MIMBAR PGSD, 2.1 (2014), 1-10. 
dalam mengikuti pembelajaran. Analisis dalam proses pembelajaran meliputi tiga hal, yaitu: a) general characteristics, b) specific entry competencies, dan c) learning style ${ }^{33}$.

2. State performance objectives, langkah selanjutnya ialah dengan cara menetapkan tujuan secara spesifik, karena tujuan bukanlah suatu hal menjadikan syarat wajib pembelajaran yang harus dicapai, melainkan tujuan itu sendiri adalah sebuah pernyataan singkat yang menggambarkan bagaimana tujuan akan dicapai ${ }^{34}$.

3. Select methods, media, and materials, dalam hal ini pemilihan metode, media dan materi harus disesuaikan dengan kesepakatan yang ditetapkan dalam capaian kompetensi atau standard pembelajaran.

4. Utilize materials, pemakaian materi, media dan teknologi sangat mempengaruhi terhadap hasil pembelajaran atau pengalaman bagi mahasiswa.

5. Require learner participation, agar pembelajaran berjalan secara efektif maka diperlukan adanya partisipasi mahasiswa dalam mengikuti perkuliahan dengan tujuan agar segala pengetahuan atau pengalaman baru yang terdapat dalam perkuliahan dapat diterapkan.

6. Evaluate and revise, dari berbagai tahapan-tahapan yang telah dilakukan untuk membuktikan adanya hasil dari pembelajaran maka dilakukanlah sebuah evaluasi sebagai wujud untuk mengetahui sejauh mana pencapaian dalam pembelajaran yang telah berlangsung.

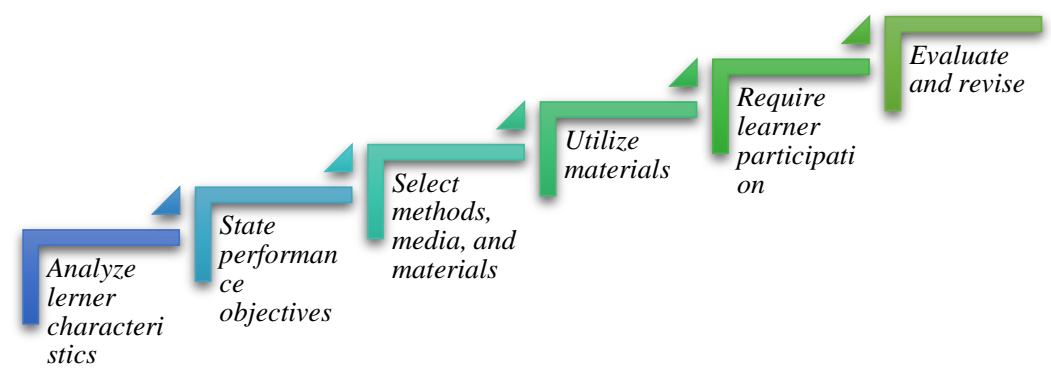

Gambar 1.2: langkah-langkah dalam pendekatan ASSURE

\footnotetext{
${ }^{33}$ Baharun.

${ }^{34}$ Budi Purwanti, 'Pengembangan Media Video Pembelajaran Matematika Dengan Model Assure', Jurnal Kebijakan Dan Pengembangan Pendidikan, 3.1 (2015), 42-47.
} 


\section{PENERAPAN RECIPROCAL TEACHING BERBASIS TEKNOLOGI DENGAN PENDEKATAN ASSURE DI PERGURUAN TINGGI}

Perguruan tinggi merupakan sebuah instansi yang didalamnya bertanggung jawab atas kesuksesan generasi masa depan dalam bidang ilmu pengetahuan dan teknologi (IPTEK). Sehingga dalam penanggung jawaban tersebut dibutuhkanlah suatu pemikiran dalam mencapainya.

Menurut beberapa pendapat menyatakan bahwa pada era saat ini, perguruan tinggi masih berada dalam ambang kecemasan. Karena sebagaian besar instansi di perguruan tinggi yang proses pembelajarannya masih kurang kondusif dikarenakan alokasi penjadwalan jumlah SKS yang terbatas. Dengan keterbatasn tersebut, menjadikan sebuah PR terhadap dosen dan dan pimpinan yang ada diperguruan tinggi dengan menuntut dapat melahirkan out put yang berilmu dan berakhlak atau ilmuwan yang berkuwalitas.

Sehingga dibutuhkanlah sebuah pendidikan yang akan menjadi pelengkap, karena dalam sebuah instansi tidak akan kondusif proses pencetak generasi jika tidak disertai dengan adanya pendidikan. Begitu pula dengan pendidikan, ia akan berjalan sesuai dengan prosedur yang ada jika disertai dengan adanya proses pembelajaran disertai penerapan model pembelajaran dan pendekatannya yang sekiranya dapat mendukung terlaksananya suatu pembelajaran khususnya di perguruan tinggi.

Model pembelajaran yang dimaksud merupakan suatu usaha yang dapat menjadikan proses pembelajaran berjalan dengan efektif dan efisien. Selain itu, dalam model pembelajaran juga dibutuhkan keaktifan dan kekreatifan dosen maupun mahasiswa dalam mengikuti perkuliahan.

Berdasarkan paparan diatas, maka model pembelajaran yang sesuai dengan keadaan saat ini adalah model pembelajaran reciprocal teaching. Model pembelajaran reciprocal teaching menjadi salah satu model pembelajaran yang dapat merangsang dan memikat mahasiswa untuk mengikuti peruliahan secara mandiri. Proses pembelajaran yang terjadi dengan model ini menjadikan mahasiswa untuk selalu pro aktif dalam menekuni mata kuliah yang sedang dipelajari.

Dalam pembelajaran dengan menggunakan model reciprocal teaching menjadikan mahasiswa menemukan pengalaman dan pemahaman baru dengan karya imajinasi yang lahir dari dirinya sendiri serta mampu untuk menjadikan mahasiswa 
aktif kreatif dan produktif dalam segala hal nyata yang dapat menjadikan motivator untuk berimajinasi dan berpikir positis serta memapar dan mendemostrasikan hasil dari pemikirannya.

Selain model pembelajaran mendukung atas terjadinya proses pembelajaran diperlukan pula pendekatan pembelajaran yang akan membantu untuk mensukseskan proses pembelajaran. Di era saat ini yang dipenuhi dengan berbagai macam kecanggihan teknologi, maka pendekatan pembelajaran yang sesuai dengan model pembelajaran reciprocal teaching yang berada di perguruan tinggi adalah dengan menggunakan pendekatan ASSURE.

Pendekatan ASSURE merupakan sebuah pendekatan yang dalam pelaksanaannya fokus terhadap pemanfaatan media. Media yang dimaksud adalah media yang berbasis teknologi, karena dalam kurun waktu yang sudah mulai memasuki era reformasi 4.0, teknologi menjadi nomor satu dalam hal bidang pendidikan yang akan menjamin terhadap mutunya suatu pendidikan.

Dalam pendekatan ASSURE mahasisiwa diajak untuk aktif dalam mengikuti pembelajaran serta mampu untuk merancang sebuah program pembelajaran yang dapat menciptakan suasana pembelajaran yang menarik dan menyenangkan. Sehingga dalam pendekatan ASSURE terjadi sebuah perubahan paradigma dalam pembelajaran yaitu dari teacher centered menjadi student centered. Hal ini terjadi karena dalam proses pembelajaran lebih mementingkan dan memanfaatkan materi dari pada penjelasan yang dipersentasikan oleh guru.

Dari penjelasan singkat tersebut, maka diperlukan adanya konstribusi antara model pembelajaran reciprocal teaching dengan pendekatan ASSURE, karena keduanya memiliki tujuan yang sama yaitu menjadikan mahasiswa aktif dan kreatif dalam mengikuti perkualiahan. Sebagai upaya dalam pencapaian yang diharapkan maka perlu dicantumkan langkah-langkah dalam penerapan model pembelajaran reciprocal teaching dengan pendekatan ASSURE.

Adapun langkah-langkah dalam model reciprocal teaching adalah sebagai berikut:

1. Pemberian materi perkuliahan yang sesuia dengan jadwal mata kuliah oleh dosen

2. Membagi mahasiswa menjadi beberapa kelompok kecil

3. Membagikan teks bacaan sesuai dengan tema yang ada dalam mata kuliah

4. Pada langkah pertama dosen bertindak sebagai model 
5. Memberikan empat pemodelan sesuai dengan yang ada dalam model pembelajaran reciprocal teaching yaitu memprediksi, mengklarifikasi, membuat pertanyaan dan merangkum

6. Menunjuk salah satu dari mahasiswa untuk menjadi pengganti perannya sebagai model dan bertindak sebagai pemimpin diskusi dalam kelompok. Mahasiswa dilatih dan diarahkan untuk berperan sebagai model dalam setiap kegiatan yang sedang berlagsung.

Sedangkan langkah-langkah dalam penerapan ASSURE, sebagai berikut:

1. Mengidentifikasi serta menganalisa karakteristik mahasiswa

2. Mencantumkan dan merumuskan segala hal yang menjadi harapan dalam tercapainya pembelajaran yang diikuti oleh mahasiswa

3. Memilih media, strategi dan materi sesuai dengan standard atau tujuan pembelajaran

4. Memanfaatkan media dan materi secara keseluruhan

5. Merealisasikan partisipasi aktif dalam mengikuti semua pembelajaran.

Berdasarkan dari langkah-langkah yang ada baik dalam model pembelajaran reciprocal teaching dan pendekatan ASSURE terdapat sebuah persamaan lain yang dapat menjadi pembantu dalam pelaksanaannya, yaitu dengan hadirnya strategi ARCS dalam keduanya.

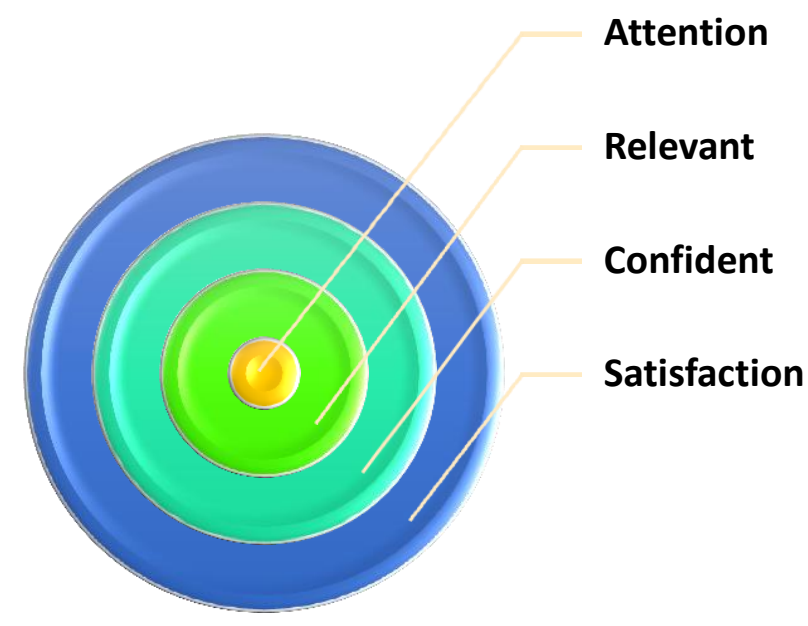

Gambar 1.3: persamaan strategi dalam model pembelajaran reciprocal teaching dan pendekatan ASSURE 
Dari persamaan strategi tersebut akan lahir sebuah komitmen yang dapat membangun mahasiswa untuk lebih perhatian terhadap perkuliahannya, mengaitkan segala hal yang dilakukan itu ada kaitannya dengan kebutuhan dan tujuan hidup, pendesainan pembelajaran dengan adanya kekreatifan dan keaktifan dosen dan mahasiswa dapat membantunya dalam mengetahui pemaknaan pengetahuan secara nyata dan setelah mahasiswa mengalami ketiga strategi tersbut ia akan merasakan kepuasan dari apa yang telah dilakukan dan yang usahakannya selam proses pembelajaran berlangsung dengan keterbatasan penjadwalan SKS yang diikuti selama perkuliahan.

\section{KESIMPULAN}

Dalam rangka mengefektifkan pembelajaran, pemilihan model pembelajaran yang efektif dan efisien sangat diperlukan, khususnya di perguruan tinggi, mengingat karakteristik peserta didiknya (mahasiswa) yang memiliki pemikiran yang baik dan kritis. Melalui moedel reciprocal teaching berbasis teknologi dengan pendekatan ASSURE di perguruan tinggi, maka aktivitas pembelajaran akan mampu membangkitkan motivasi belajar, kreativitas, kemandirian, nalar kritis mahasiswa sehingga target pembelajaran akna dapat tercapai secara optimal.

Reciprocal teaching berbasis tekhnologi dengan pendekatan ASSURE di perguruan tinggi juga bisa menciptakan kondisi yang lebih bermakna, membentuk kepribadian, bersikap inklusif, membangun higher other thinking skill, creativity skill mahasiswa, sehingga mampu menciptakan generasi yang unggul, berkarakter sesuai dengan kepribadian bangsa dan tanah air, sesuai dengan tujuan pelaksanaan pendidikan dan pembelajaran di Indonesia.

\section{DAFTAR PUSTAKA}

Abdul Qohar dan Utari Sumarmo, 'Improving Mathematical Communication Ability and Self Regulation Learning Of Yunior High Students by Using Reciprocal Teaching', IndoMS. J.M.E, 4 (2013), 59-74

Adhani, Aidil, 'Pengaruh Strategi Pembelajaran Reciprocal Teaching Dan Kemampuan Akademik Terhadap Aktivitas Lisan Dan Hasil Belajar Kognitif Biologi', Jurnal Pendidikan Sains, 2 (2014), 148-58 
Afandi, 'Pembelajaran Biologi Menggunakan Pendekatan Metakognitif Melalui Model Reciprocal Teaching Dan Problem Based Learning Ditinjau Dari Kemandirian Belajar Dan Kemampuan Berpikir Kritis Mahasiswa', Jurnal Pendidikan Matematika Dan IP A, 2 (2011), 1-7

Baharun, Hasan, 'Pengembangan Media Pembelajaran PAI Berbasis Lingkungan Melalui Model ASSURE', Cendekia: Journal of Education and Society, 14 (2016), 231-46

Budi Purwanti, 'Pengembangan Media Video Pembelajaran Matematika Dengan Model Assure', Jurnal Kebijakan Dan Pengembangan Pendidikan, 3 (2015), 42-47

Eli Rohaeti, Suwardi dan Jaslin Ikhlas, Peningkatan Prestasi Dan Kemandirian Belajar Mahasiswa Melalui Pendekatan, 2010

Hasan Baharun, Vidyatul Muyassaroh, Yuli Andriana., Model Dan Desain Pembelajaran Inovatif, Kreatif Dan Berkarakter (Probolinggo: Pustaka Nurja bekerjasama dengan Duta Media, 2018)

I Gusti Ayu Martha Sari, Siti Zulaikha dan I Md. Suara, 'Pengaruh Model Pembelajaran ASSURE Berbasis Concept Mapping Terhadap Hasil Belajar IPS Siswa Kelas V SD Gugus Letkol Wisnu Denpasar Utara', MIMBAR PGSD, 2 (2014), 1-10

I Komang Agus Sethiawan, IGA Agung Sri Asri, D.B.K.T Ngr. dan Semara Putra, 'Pengaruh Model Pembelajaran Terbalik ( Reciprocal Teaching) Berbantuan Media Grafis Terhadap Hasil Belajar IPS Siswa Kelas V Semester II SD Gugus I Gusti Ketut Jelantik', Jurnal Mimbar PGSD, 2 (2014), 2014

Irma Fatehkatun Kasanah, Tri Saptuti S. dan Kartika Chrysti S., 'Aplikasi Model ASSURE Berbasis Pendidikan Karakter Untuk Meningkatkan Pembelajaran Tema Sejarah Peradaban Indonesia Siswa Kelas V SDN 1 Klapasawit', Jurnal Ilmu Pendidikan, 2 (2015), 1-5

Iwan Jazadi, 'Evaluasi Dan Pengembangan Proses Belajar-Mengajar Di Perguruan Tinggi', Jurnal Ilmu Pendidikan, 12 (2005), 1-17

Kasuwi, 'Upaya Peningkatan Kualitas Pendidikan Agama Di Perguruan Tinggi Umum', Jurnal Ilmu Pendidikan, 13 (2006), 69-74

Ni Wyn Pradnya Mitha, I Gd Meter dan I Ketut Ardana, 'Model Pembelajaran ASSURE Bernuansa Lingkungan Berbantuan Media Audiovisual Berpengaruh Terhadap Hasil Belajar IPS Siswa Kelas V SD Gugus Letkol Wisnu', Jurnal Mimbar PGSD, 2 (2014), 1-11

Putra, Yudi Yunika, and Adi Saputra, 'Pengembangan Blog Support Mata Kuliah', 11 (2018), 179-92

Ria Sardiyanti, 'Penerapan Model Pembelajaran Terbalik ( Recprocal Teaching ) Untuk Meningkatkan Aktivitas Belajar Matematika Siswa', Penelitian Tindakan Kelas Di MTs Daarul Hikmah Pamulang, 2010, pp. 1-243

Rosmalia Eva, 'Pengaruh Aplikasi Model ASSURE Terhadap Motivasi Dan Hasil Belajar Peserta Didik Dalam Pembelajaran Georafi', Jurnal Pendidikam Geografi, 15 (2015), 8-14

Sriyani Ketong, Burhanuddin dan Wahyu Kurniati Asri, 'Keefektifan Model Pembelajaran Reciprocal Teaching Dalam Kemampuan Membaca Memahami Siswa Kelas XI IPA SMA Negeri 11 Makassar', Eralingua: Jurnal Pendidikan Bahasa Asing Dan Sastra, 2 (2018), 45-54

Surya Dharma \& Husaini Usman, 'Konsepsi Dan Aksi Sinergi Perguruan Tinggi, 
Pemerintah Daerah, Dan Dunia Usaha/Industri', Jurnal Ilmu Pendidikan, 14 (2007), 1-9

Widia Maya Sari dan Endang Susiloningsih, 'Penerapan Model ASSURE Dengan Metode Problem Solving Untuk Meningkatkan Keterampilan Berpikir Kritis', Jurnal Inovasi Pendidikan Kimia, 9 (2015), 1468-77

Widiya Pakartining Kawedar \& Abdul Qohar, 'Penerapan Model Pembelajaran Reciprocal Teaching Untuk Meningkatkan Hasil Belajar Siswa Pada Pokok Bahasan Segitiga Siswa Kelas VII-C SMP Negeri 2 Kepanjen', Jurnal Matematika, 2 (2015), 1-9

Winda Maulina, Thamrin Kamaruddin dan M. Yusuf Harun, 'Penerapan Model Pembelajaran ASSURE Untuk Meningkatkan Hasil Belajar Geografi Siswa Kelas XI IPS SMA Negeri 12 Banda Aceh', Jurnal Ilmiah Mahasiswa Pendidikan Geografi, I (2016), 203-11 